\title{
The Constrained Air Transport Energy Paradigm in 2021
}

\author{
Abel Jiménez-Crisóstomo ${ }^{1}$ (D), Luis Rubio-Andrada ${ }^{2}$, María Soledad Celemín-Pedroche ${ }^{3, *(D)}$ \\ and María Escat-Cortés ${ }^{3}$ (D) \\ 1 Department of Economic Structure and Development Economics, Autonomous University of Madrid, \\ 28049 Madrid, Spain; abel.jimenez@uam.es \\ 2 Department of Applied Economics, Autonomous University of Madrid, 28049 Madrid, Spain; \\ luis.rubio@uam.es \\ 3 Department of Business Organization, Autonomous University of Madrid, 28049 Madrid, Spain; \\ maria.escat@uam.es \\ * Correspondence: marisol.celemin@uam.es
}

check for updates

Citation: Jiménez-Crisóstomo, A.;

Rubio-Andrada, L.;

Celemín-Pedroche, M.S.; Escat-Cortés, M. The Constrained Air Transport

Energy Paradigm in 2021.

Sustainability 2021, 13, 2830. https://

doi.org/10.3390/su13052830

Academic Editor: Luis Delgado

Received: 31 December 2020

Accepted: 2 March 2021

Published: 5 March 2021

Publisher's Note: MDPI stays neutral with regard to jurisdictional claims in published maps and institutional affiliations.

\begin{abstract}
The increasing relevance of air transport as a contributor to climate change requires the development of emissions reduction technologies in a socio-economic and cultural context, where demand and air traffic have traditionally held sustained growth rates. However, the irruption of COVID-19 in 2020 has had an enormous negative impact on air travel demand and traffic volumes. Coincidentally, during 2020, new technology proposals for emissions reduction based on use of hydrogen and synthetic fuels have emerged from the aviation stake holders. By following a novel approach connecting the analysis of expectations of technology developments and their deployment into the fleet to market constraints, this study discusses how, even considering the new technology proposals and even if the COVID-19 has led to a completely different scenario in tourism and aviation, the air transport energy paradigm will remain unchanged in the upcoming decades as a consequence of market constraints, aircraft complexity, compliance with safety requirements, and extended life cycles. In this frame, aviation needs to keep on pursuing the abatement of its emissions while managing social expectations in a realistic manner and leaning on compensation schemes to achieve emissions contention while new technologies become serviceable in the longer term.
\end{abstract}

Keywords: sustainability; energy; air transport; climate change; emissions trade systems; COVID-19

\section{Introduction}

In fall 2019, sustained growth of air traffic was an undisputed assumption that was considered in all scientific studies about aviation sustainability [1-6]. At that time, the authors of this article analyzed the technological, market and safety constraints that prevented a radical change in the air transport energy paradigm. Evolution towards new energy paradigms consistent with a sustainable economic development while limiting climate change and other externalities is a strategic goal for policy makers, governments, and public administrations [7]. Said evolution is factual for most economic sectors [8,9] and is also pursued in air transport through multiple technical initiatives: electrical aircraft, hybrid propulsion, development of biofuels, etc. [10]. Moreover, energy efficiency is of paramount importance for air transport, as the fuel bill represents the main cost to airlines, averaging $23.7 \%$ of their operating expenses during 2019 [11]. Improvements in energy efficiency have therefore a two-fold positive effect in the sector, simultaneously enhancing its sustainability and competitiveness.

$\mathrm{CO}_{2}$ aviation emissions in 2019 ranged between slightly over $2 \%$ according to the International Aviation Transport Association (IATA) [12] and 2.8\% according to the International Energy Association (IEA) [13], with the sector accounting for an overall $3.5 \%$ of the full anthropogenic climate impact [14].

The aviation sector's commitment to the Sustainable Development Goals (SDG) is explicitly expressed by the International Organization of Civil Aviation (ICAO) and it 
also explicitly refers to initiatives to reduce fuel consumption, the use of alternative fuels, improvement of operations, and deployment of market-based schemes, ultimately oriented at containing and reducing emissions in support of SDG 13 (take urgent action to combat climate change and its impacts) as well as other SDGs [15]. According to EUROCONTROL [16], awareness of the impacts of climate change in the sector is growing among its stakeholders, and the majority of them are already taking actions to adapt. Within its environmental strategy objectives, ICAO also aims at understanding and abating the impacts of noise and emissions that affect local air quality and health by developing environmental standards and recommended operational practices, which contributes to SDG 3 (ensure healthy lives and promote well-being for all at all ages) [15].

Irruption of COVID-19 during 2020 has led to a brutal reduction of air traffic $[17,18]$ \{Formatting Citation\} [18] and has also affected aircraft production [19,20]. COVID-19 effects in aviation are being analyzed by academia. Airlines are attempting to minimize the erosion of long-developed market capabilities, route networks, and prior relationship of trust with customers [21]. Airlines need help to survive in the short term without discarding commitments toward decarbonization and a sustainable global economy [22]. Abate et al. [23] see an opportunity in conditioning government support to the adoption of operational models and technologies aiming at achieving social and environmental goals.

Gössling [24] identifies COVID 19 as a chance to rethink global air transport by challenging the current assumptions on which the sector operates (volume of growth, state aids, and unresolved environmental impacts), where a reduced supply would be an opportunity for airlines to increase profitability while yielding a more resilient aviation system.

Coincidentally, during 2020, aviation stake-holders, both institutional and corporate, have come up with new technology proposals for emissions reduction based on the use of hydrogen and synthetic fuels $[25,26]$ backed up by European Union policy strategies on hydrogen economy development (a hydrogen strategy for climate-neutral Europe, [27], published in July 2020) as well as sustainable and smart mobility (Sustainable and Smart Mobility Strategy - putting European transport on track for the future, [28], published in December 2020).

In this complex frame, questions arise on whether the same constraints limiting the change in the aviation energy paradigm identified and analyzed in fall 2019 are still applicable in this new scenario subject to the impacts of COVID-19 and where new technology proposals have been postulated, and what the likelihood is of a revolutionary paradigm change in the upcoming decades.

The proposal in this paper is to respond to said questions analyzing the pre-COVID-19 and 2020 situations following a scenario study approach. In part 1, the pre-COVID19 scenario of sustained traffic growth and aircraft demand is assessed considering the technology proposals under discussion at the time. In part 2, an analysis will be done assessing how COVID-19 traffic downturn and uncertain market recovery together with the irruption of new technology proposals have changed the original scenario. In part 3, final conclusions will be captured, showing that in the new scenario, some of the original constrains have been relaxed, some other remain applicable, and some new others have been identified that keep limiting the ability to achieve a revolutionary change in the energy paradigm of air transport. Therefore, mid-term expectations and recommendations with regards to air transport sustainability do not fundamentally change, irrespective of the very different scenarios.

\section{PART 1. Pre-COVID-19 Scenario, Fall 2019}

\subsection{Air Transport Demand Evolution and Projections}

During the 60s and 70s, technical improvements in aircraft and infrastructure enabled air transport development to become a "mass production" system. Hernández [5] identifies social improvement elements like personal income growth, incorporation of women to the labor market, generalization of paid holidays, higher availability of leisure time, and 
increased longevity as key elements concurring with those technical improvements that allowed for the rapid growth of long distance tourism.

Upon the "Deregulation Act" in USA [29], air transport started a deregulation process evolving towards a free competition market. Business models were transformed, leading to a progressive and steady reduction in costs and prices. Low cost carriers proliferated, becoming key in granting access to air transport to the global public.

The Japan Aviation Development Corporation, JADC, World-Wide Market Forecast 2019-2038 [30] analyzes the motivations of international travellers in 2017, finding that $82 \%$ travel for leisure or visits to friends and relatives.

Scott and Gössling [31] identify a good correlation between tourism development and international air traffic arrivals. Based on that, Gössling, Hall, Peeters, and Scott [3] analyze tourism growth tendencies and identify three main vectors for the future: growing demand, long haul growth (expected to triple between 1995 and 2020), and shorter and more frequent holidays.

Gössling, Hall, Peeters, and Scott [3] discuss how the symbiotic growth of air transport and tourism is an indisputable paradigm in both sectors, and how there is no country intending to set limits to the number of visitors. Emission reduction measures rely exclusively on technology improvements. No strategies are envisaged to promote changes in tourists' behavior or set limits to travel demand. Gössling and Cohen [32] also remark that emerging societal structures involve more travel (visiting relatives and friends, health and religion driven), which is not necessarily perceived as discretionary.

Ram, Nawijn, and Peeters [33] analyze travellers' motivations, and identify the search of happiness through changes and novelties, which is catalyzed by the perception of creating distance from their routine. This leads to travellers' consciously unsustainable behavior, covering bigger distances during their holidays. Higham et al. [34] conclude that voluntary approaches, such as voluntary carbon off-setting, are viewed with widespread scepticism and will not be sufficient to induce a change in in air travel practices so to achieve radical emissions reduction.

Larsen and Guiver [35] analyze how physical distance itself constitutes a psychological value to the traveller, as it represents getting away from their daily lives.

Air transport and tourism stakeholders agree on a scenario of traffic growth in the upcoming decades. Thus, annual air traffic is expected to double in the next fifteen years following the same pattern of the last 30 years [36]. Moreover, according to EUROCONTROL, operations and airport congestion are seen as one of the main aviation challenges for the next decades [16].

\subsection{Air Transport Supply. Future Aircraft Demand Projections}

The growing traffic context demands high aircraft production rates and improvements on operation efficiency to allow for airlines survival in a highly competitive environment with declining yield rates.

According to data from JADC [30], most of the air transport supply (measured in available seat kilometers-ASKs) is covered by airliners exceeding 120 seats (narrow- and wide-body jets).

During the last years, the aeronautical industry has followed a strategy of improving existing airliners as the A320-NEO (new engine option), family (EASA type certified in November 2015), and the B737 MAX (EASA type certified in March 2017). Aircraft manufacturers have avoided developing totally new aircraft with disruptive technologies and higher technical risk.

In May 2019, Boeing orders on existing models accounted for 5764 aircraft, including 4550 units of B737-MAX, a model currently waiting for recovering its airworthiness approval, were revoked after the Lion Air accident in October 2018 and Ethiopian Airlines' in March 2019. Its competitor, Airbus, had in May 2019 an order booked of 7207 aircraft. 
With current production rates close to the maximum productive capacity of their plants and their supply chain, this implies that in the next 10 to 12 years the production capacity would be fully occupied manufacturing existing models.

Boeing's market projections in 2019 [37] reflect new aircraft deliveries up to 2038 in 44,040 units $(41,800$ if regional aircraft are excluded). Airbus predictions in their 2019 Global Market Forecast [36] are slightly more conservative, quoting 37,390 aircraft to be delivered in the same period. Considering either of those predictions and the standing orders in May 2019, and considering current production rates, it can be observed that approximately one fourth to one third of new commercial aircraft entering into service in the next 20 years have already been ordered. Current production rates would hardly cover half of the predicted demand, so would need to be increased.

At the end of 2038, a significant number of aircraft already in service will remain operative (10,600 according to Airbus and 6620 as per Boeing predictions). The pre-existing fleet has a significant inertia to stay. Average aircraft operating lives have been very stable since 1993: around 20 years for widebodies and slightly higher for single-aislers, with freighters lasting an average of 30 years [37]. Analyzing data of existing aircraft and expected survival rates after 20 years, lives would need to be extended to 23.5 years according to Boeing data and to almost 30 according to Airbus'.

Technology enhancements supporting the next generation of aircraft will be based in new more efficient engine architectures, but still based in a combustion and reaction energy paradigm, such as UltraFan ${ }^{\circledR}$ or Propfan. Assuming optimistically entry into service of the first aircraft product featuring this technology in 2028 and making the ultra-optimistic assumption of all new aircraft (all segments, all manufacturers) produced in the second half of the prediction period featuring the new technology, at the end of the 20 years, only half of the new produced aircraft and approximately $40 \%$ of the total fleet would benefit from it. The UltraFan ${ }^{\circledR}$ technology is expected to yield a $25 \%$ specific fuel consumption reduction [38] with respect to 2000 levels (less than $1 \%$ per year). The alternative Propfan could yield up to a $30 \%$ specific fuel consumption improvement [39], but the integration with the aircraft will require longer technology maturation times. There are currently no expectations of Propfan applications entering into service in the next decade.

Development of new aircrafts relying on new technologies implies long-uncertain development times. Figures 1 and 2 show the development chronograms of the most recent brand-new design aircraft: Boeing B787 and Airbus A350.

Aircraft manufacturers carry out numerous concept design iterations while holding discussions with customers to determine the product specification [40]. Meanwhile, the manufacturers start to strategically align their key systems and parts suppliers. This is an iterative process of uncertain conclusion that takes years if not decades. Even after a formal product launch, significant changes to the specification and the concept design may happen as a result of changes in customer requirements or technical difficulties arising during the design and development.

Usually, the new application is given a preliminary name when the project is formally launched, and the funding is committed. Eight years were elapsed between Boeing Dreamliner "baptism" in 2003 and 787 entry into service in 2011. Ten years was the time span between A350 programme launch in 2005 and its service start in early 2015. 


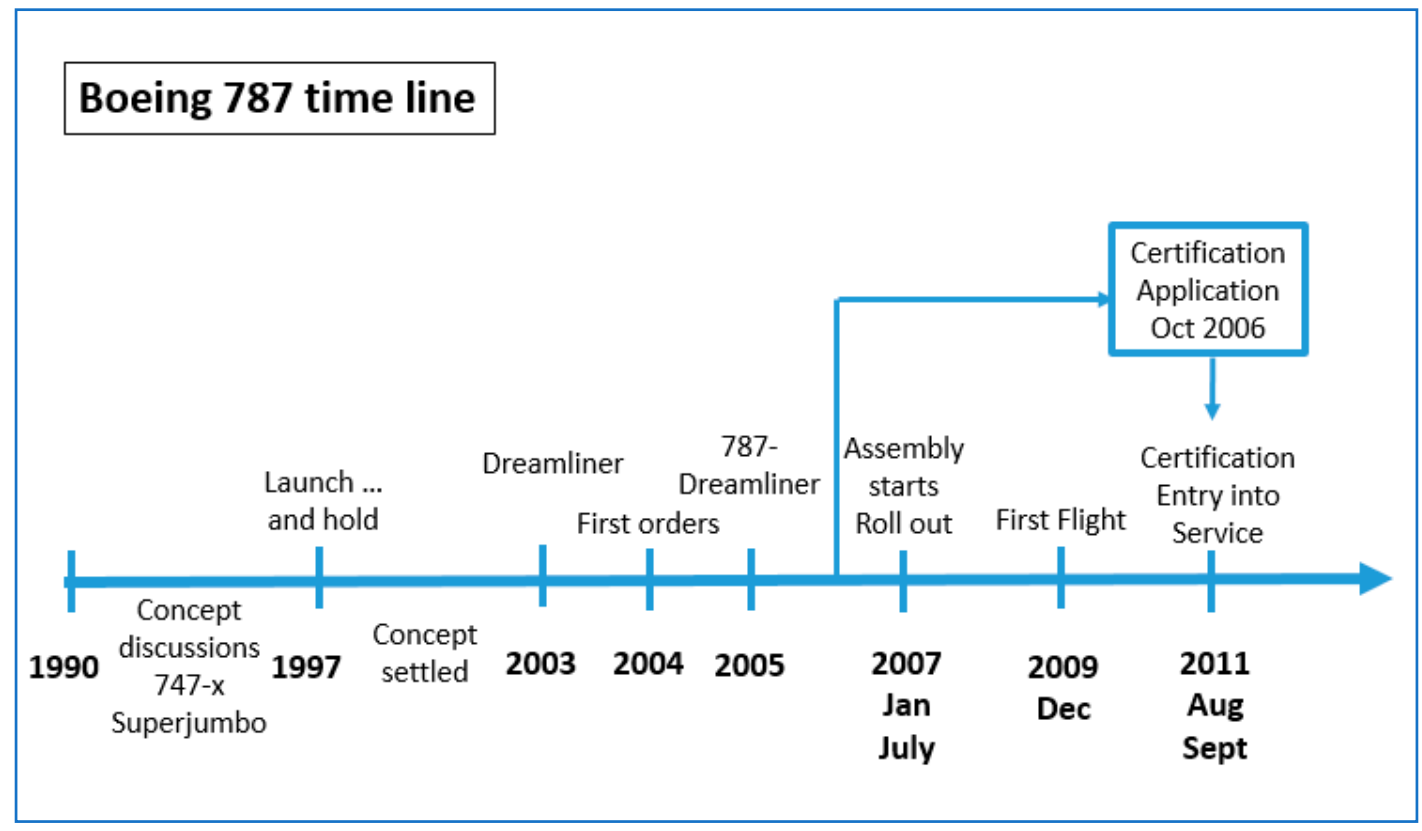

Figure 1. Boeing B787 development timeline.

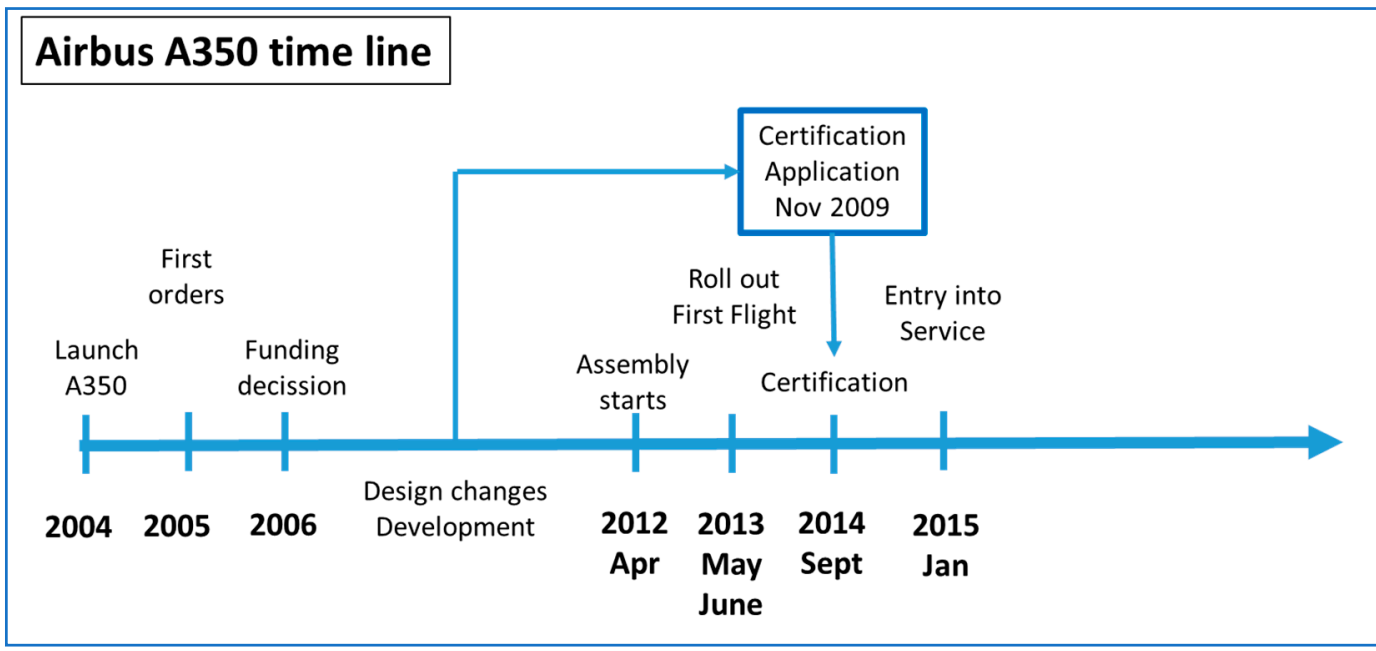

Figure 2. Airbus A350 development timeline.

In September 2019, the only "informally nominated" aircraft project susceptible of incorporation of new technologies was the Boeing 797, a midsize 250-270 passenger wide body that Boeing planned originally to get into service in 2025. However, the program was not formally launched nor funded beyond concept studies.

Another relevant aspect affecting the difficulty of taking a new aircraft design into service is the certification process and lead-time. Approximately five years are required to achieve aircraft type certification according to a well settled certification base. Application of revolutionary new technologies would require definition of a new regulatory body for a product where there is no previous in-service experience proving the safety of the new design and compliance criteria. This would extend new technology aircraft certification times, as the certification criteria will be developed lagging behind the maturation of those technologies. The number of technologies that concur in aircraft development, their different regeneration times, some of them extremely long - such as the engine, and the strict safety regulations lead to a low industry clockspeed [41].

It is therefore extremely difficult to predict scenarios of introduction of new sustainabilityoriented technologies in aviation. Even under very optimistic assumptions, the high inertia 
and stiffness of the aircraft market does not allow envisaging a scenario of significant fuel consumption and emissions reduction in the commercial aircraft fleet for the next 20 years.

\subsection{Current Technology Developments. Expectations for Aviation Energy Consumption and Emissions Reduction}

Since 1960, aircraft technology developments have allowed for a reduction in energy intensity measured in megajoules per available seat kilometre of approximately 70\% [42] However, this tendency is becoming asymptotic as achieving marginal improvements in efficiency becomes more and more difficult.

According to OPEC 2016 World Oil Outlook [43], aviation oil demand in 2015 was 5.8 million daily barrels, accounting for a $6 \%$ of global oil demand. Despite all aviation system efficiency improvements, the projected aviation oil consumption for 2030 was 7.5 million of daily barrels and 8.6 million in 2040. Aviation oil demand relative to global demand will evolve from a $6.2 \%$ in 2015 to a $7.9 \%$ in 2040 .

Improvements in system efficiency can be achieved at three levels:

1. Operations and air traffic control. Nations have traditionally been very zealous to keep tight control on the air traffic in their airspace. This fact has limited along the years the progress towards more efficiently integrated multinational systems. EUROCONTROL is a pan-European, civil-military organization dedicated to supporting European aviation in air traffic management. EUROCONTROL promoted the SESAR (Single European Sky ATM Research) Joint Undertaking initiative [44], whose objectives are to triple the current European Air Space capacity, improve system safety by a factor of 10 , reduce by $10 \%$ the environmental impact of each flight, and reduce air traffic management (ATM) costs by 50\%. SESAR's goals are not by themselves consistent with an aviation sustainability intent. Although the $10 \%$ reduction in environmental impact per flight suggests a commitment to an environmentally friendly aviation, these improvements would be by far exceeded by the impacts derived from tripling of the airspace capacity and the increase in air traffic demand motivated by the prices decrease consequence of the $50 \%$ reduction in air traffic management costs.

2. Aircraft improvements. Aircraft aerodynamic design is subject to continuous improvements granted by new design methodologies. However, in the last decades, these improvements are becoming marginal. Better aircraft efficiency is also achieved by reducing weight. Most recent generation aircraft (B787 and A350) achieved relevant weight reductions by a wide utilization of composite materials. B787 also pioneered replacement of pneumatic and hydraulic electrical systems $[45,46]$, cutting some weight at the cost of new safety risks [47] and significant certification difficulties [48]. These evolutionary technologies provide modest marginal improvements in overall efficiency. More revolutionary aircraft concepts have been historically explored and are still subject to investigation:

(a) Blended wing bodies (BWB): the traditional aircraft configuration consisting of center cylindrical non aerodynamic fuselage lifted by aerodynamically shaped wings is far from being the optimum aerodynamic concept. There is a significant aerodynamic advantage in integrating wings and fuselage in a single lifting, reduced drag body. Potential fuel consumption savings can reach up to $27 \%$ [49]. The main technical challenges of the concept are the difficulty of controlling the aircraft and the big central volume, which introduces complexity in the pressurization system and complicates compliance with emergency evacuation certification requirements. Customer perceptions potentially leading to concept rejection are also a concern, since the BWB can only feature a limited number of windows and because of the very large movements that the passengers close to the wing tips will experience [50].

(b) Ekranoplanes: this aircraft concept relies on the so-called ground effect to generate higher lift per wing surface area, therefore increasing aircraft aerodynamic efficiency [51]. By flying very low over flat surfaces (water or snowed 
plains), the wings and ground form a fluid channel, increasing air flow pressure and, consequently, lift. Therefore, for a given wing surface, higher aircraft loads can be transported. Its efficient operation is therefore limited to environments and conditions where the ground flatness can be guaranteed, which invalidates this solution for a widespread commercial application. Additionally, the ekranoplanes suffer from important stability problems [51]. During the Cold War, the Soviet Union developed several ekranoplanes under military specifications. Boeing has also studied the concept [52]. Studies have been carried out that preliminarily identify potential exploitation niches for ekranoplanes, but confirm the difficulties of becoming a significant commercial traffic volume handler [53,54]. All the technologies discussed so far in this section, except the ekranoplane, were qualified by Peeters, Higham, Kutzner, Cohen, and Gössling [6] as technology myths, as at some point in time they have been described by industry and media as definitive solutions for aviation sustainability when, in reality, their viability is questionable and/or their sustainability impact is very limited.

3. Improvements in aircraft propulsion systems. Propulsion is the aviation discipline more intrinsically related to aviation environmental impact. Engine industry continuously works on turbomachinery enhancements, improving aerodynamics and the use of lighter materials capable of holding higher temperatures and stresses [50]. Historically, those enhancements have allowed for an average 1\% efficiency improvement annually. Higher efficiency improvements require a fundamental architectural change in the engine, but even with that, the average annual improvement of $1 \%$ is not expected to be exceeded, as the overall efficiency increase would have to be distributed along the time required to develop such architectural changes and their entry into service. There are currently two new engine architecture concepts at technology demonstration phase:

(a) Propfan. This is an intermediate concept in between the propeller engine (turboprop) and the turbofan. It is particularly efficient for climb and descent, so it provides optimum performance for short and medium range flights. The Propfan presents huge technology challenges: very high noise levels, difficulties of integration with the aircraft, high vibrations, and high maintenance costs. The Propfan was already studied in the eighties by Pratt and Whitney and General Electric, but the investigation was abandoned upon a drop in oil prices [39]. Propfan technology is being developed in European Programs Clean Sky 1 and 2 [39]. However, there is currently no commercial aircraft program identified intending to apply this technology.

(b) Turbofan with reduction gearbox and high bypass ratio. The introduction of a reduction gear box allows for optimization of the speed ratio between the front fan and its driving turbine, permitting the increase of fan size and yielding a higher propulsive efficiency. The main technical challenge is the reduction gear box itself, particularly for high thrust engines, where power transmitted could reach up to a hundred thousand horsepower. The concept was already developed by Pratt and Whitney for a mid-size engine in the Airbus A320 NEO (named Geared Turbo Fan-GTF) and has already been in service since 2016, more than 20 years after the concept development was started [55]. Rolls-Royce, within the Clean Sky 2 program, is developing an equivalent concept for large aircraft (Airbus A350 size), the UltraFan ${ }^{\circledR}$ [38]. Several ground test demonstrators will be run to finally install an engine on a flying test bed. The program aims at achieving the bulk of technology and architecture demonstration in 2023. The UltraFan ${ }^{\circledR}$ technology challenge is consistent with an expectation of entry into service within the next 10 years.

(c) Electric propulsion. Electric motors are highly efficient, do not produce GHG or air polluting gases, and generate significantly lower noise levels than jet en- 
gines. Utilization of renewable energies in the aircraft requires a higher degree of systems electrification and use of batteries for energy storage. Current state of the art batteries offer a much lower energy intensity than kerosene, requiring 18 times the volume and weighting between 60 and 70 times more [56]. These ratios make a full electrical aircraft hardly viable, and its application can only be envisaged for short range, very low pay load applications. Additionally, the integration of the propulsion electrical system in the aircraft implies dramatic changes in aircraft architecture. Aircraft capacity reduction induced by electrification and use of batteries can be analyzed through the payloadrange diagrams. For a 162-passenger configuration, a Boeing 737-800 yields a range of 3000 nautical miles [57]. By simply replacing fuel weight by batteries, and assuming aircraft performances remain the same, applying the aircraft range equations for electrical aircraft derived by Hepperle [56], the resulting B737-800 range would be 73 nautical miles. In reality, such an aircraft would hardly be able to take off, as the equations are only valid for operations where most of the energy consumption happens during a long cruise leg, so the consumption during the other phases is considered negligible. The energy allowing for a cruise flight of 73 miles would not be enough to perform a take-off and climb to cruise level. Replacement of payload by batteries to get extra range would yield very little benefit and would require a different aircraft design, contrasting with the flexibility of the traditional fuel aircraft, where payload can be traded by fuel by simply limiting aircraft loading or introducing cabin configuration changes. This simple example illustrates the unviability of pure electrical aircraft for typical commercial airliners. Hepperle [56] studied the viability of regional aircraft (Do 328 turboprop) powered by batteries to conclude that current energy intensity levels (around $180 \mathrm{Wh} / \mathrm{kg}$ ) would need to be factored by more than $10(2000 \mathrm{Wh} / \mathrm{kg})$ to nearly match the current aircraft production capacity. It is not likely that this could happen in the next 20 years while simultaneously integrating that technology in a safe and certifiable aircraft. The viability niche of electrical propulsion in aviation is closer to personal and urban transportation, with small payloads and ranges.

(d) Hybrid propulsion partially mitigates the problem of battery weight by distributing the system energy capacity among fuel feeding, a gas turbine, and batteries. Fuel is burnt in the gas turbine that drives an electric generator, which provides electricity for batteries loading. Batteries feed the electric motors that provide aircraft propulsion. During take-off and climb, the electric motors consume battery electricity exceeding the generator charging capacity. Battery load is recovered during cruise. Hybrid propulsion extends the viability range (in terms of payload-range combinations) of pure electrical propulsion [56]. However, its higher degree of complexity requires longer development times. Airbus and Rolls-Royce are partnering up in developing this technology in the E-Fan X program [58].

4. Alternative fuels. Benito and Benito [59] reviewed the different fuels that have been considered in aviation alternatively to kerosene. Investigations have been carried out about hydrogen applications and even small nuclear reactors. Both concepts are highly energy efficient but are not viable in the mid-term due to safety, logistic, and storing concerns. Biofuels are the most viable alternative to kerosene. They offer three main advantages:

- Regeneration capacity.

- $\mathrm{CO}_{2}$ emissions during production process and final combustion are partially compensated during their vegetal life.

- Drop-in capacity: biofuels can be fed into the existing aircraft fuel systems and engines, although the mixing ratio shall be controlled and traced. 
First generation of biofuels was obtained from traditional crops, many of them for human feed: sugar cane, corn, palm, and soy. Use of alimentary crops was a matter of criticism; therefore, a second generation of biofuels based on lignocellulosic and nonalimentary vegetal oils (jatropha or cameline) was developed. Criticism still remained, as these crops could displace alimentary species from croplands [60]. Benito and Benito [59] remark that the extension of cropping land required to produce biofuels for full aviation coverage will be four times the surface of Spain.

A third generation of biofuels is produced from algae cropping, avoiding competition with alimentary cropping lands. Algae grow rapidly, consuming high amounts of $\mathrm{CO}_{2}$ and producing higher quantities of oil than land crops. They grow in fresh and salty water, and even in wastewater (rich in carbon content).

Biofuels development is hindered by their production costs, ranging from seven to 11 times that of kerosene [61]. Productions today are evolving from laboratory size facilities to small production plants.

The European Union, in their Biofuel Flight Path program [62], fixed an objective to utilize 2 million tons of biofuels in aviation in 2020. Compared to the aviation oil consumption projection of 6.3 million barrels, it turns out that biofuels would only cover $0.6 \%$ of the global annual aviation consumption.

In conclusion, high biofuels costs and limited production capacity do not allow for a massive replacement of traditional fuels but can offer a partial mitigation of aviation emissions.

\subsection{Aviation Emissions Trade and Compensation Schemes}

The aviation community has developed attempts to implement emissions trade and compensation systems leaning on transversal compensation systems. The international character of aviation is a handicap for the implementation of said systems, as they need be applied globally to be fully efficient and not to create competition asymmetries.

Since 2010, the International Civil Aviation Organization (ICAO) has pursued implementation of a Market Based Measurement (MBM) scheme for international aviation seeking concurrence with United Nations Framework Convention on Climate Change (UNFCCC) objective of achieving stabilization of greenhouse gas (GHG) concentrations in the atmosphere and compliance with the mandate from Kyoto Protocol (1997) to reduce aviation greenhouse gases emissions (see ICAO general assembly resolutions A37-19 [63] from 2010 and A38-18 [64] from 2013).

It was during general assembly 39, in October 2016, that resolution A39-3 [65], was issued, initiating the implementation of a global plan of compensation and trade of carbon emission rights for the international aviation. The Carbon Offsetting and Reduction Scheme for International Aviation (CORSIA) was intended to be effective starting 2021 and was subscribed to by 66 nations covering $86.5 \%$ of international traffic. CORSIA implementation follows a phased approach, evolving from voluntary to compulsory adherence and considering some particular exceptions.

Resolution A39-3 [65] also defines the rules applicable to emissions measurement and register, as well as governance mechanisms. It also states that emissions units generated from mechanisms established under the UNFCCC and the Paris Agreement are eligible for use in CORSIA.

During 2019, the first emissions measurements were carried out, aiming at setting the reference scenario for 2020 and initiating the control phase in 2021.

While providing a powerful mechanism for compensation of emissions, the predicted impact in airlines costs according to ICAO [66] ranges between 0.2 to 0.6 per cent of total revenues from international aviation in 2025, and 0.5 to 1.4 per cent of total revenues from international aviation in 2035. Moreover, the expected impact in ticket prices is not expected to exceed a $0.3 \%$ increase [67], so the estimated impact in demand levels is deemed to be negligible. 


\subsection{Conclusions of Part 1}

Air traffic growth predictions assumed by private and institutional agents are based on historical data and in deep analysis of supply and demand patterns.

Tourism accounts for most of the air traffic demand. Authors like Hall [4], Ram, Nawijn, and Peeters [24] and Larsen and Guiver [35] recommend a change in demand patterns or even to impose limits on the supply side in an attempt to contain global air traffic growth and its externalities. This recommendation has recently entered into the social (flight shame-Gössling et al. [68]) and political debates (limitations to internal flights, application of green taxes on aviation, etc.). However, it is unlikely that in the mid-term air traffic demand growth will be significantly contained, since it is accepted and accounted for in future planning, by not only aviation and tourism agents, but by economic, institutional, and political stakeholders in general.

Supply will need to adapt to the growing demand, and the industry will have to produce aircraft at higher rates while improving their efficiency in order to reduce operational costs. Industry ability to introduce revolutionary aircraft changes aiming at GHG emissions reduction in this context is very limited.

In the next 20 years, only a modest part of the fleet growth will benefit from the advanced engine architectures, which will yield an improvement of fuel consumption of $25 \%$ to $30 \%$ relative to 2000 levels. It is therefore urgent that the technology demonstrators supporting these architectures are concluded and that the private-public collaboration frame is further developed to support their introduction into service in the shortest possible time frame.

Electric and hybrid technology application in aviation will require a significantly longer development time and will be limited to payload-range combinations that will not exceed those of regional aircraft. Early involvement of certification authorities is required in order to define the applicable certification frame.

Aircraft operations and traffic management improvements also have a limited potential for emissions reductions, likewise biofuels.

Aviation will, in the mid-term, enjoy availability of oil-based fuels. Consumption will grow with traffic and will drive the sector into a relatively more noticeable oil consumer and emissions generator role.

Agents of aviation and tourism will manage expectations about aviation emissions in a more realistic way, stressing the socio-economic importance of air transport.

The aspiration of air transport stabilizing its emissions needs to rely on compensation and trade schemes that allow the externalization of their compensation. This fact has been acknowledged by the aviation industry a long time ago, but only recently has the ICAO managed to define CORSIA, which is not yet in its executive phase.

\section{PART 2. 2020 Scenario: COVID-19 and New Technology Proposals}

In part 2, the authors analyze the effects of COVID-19 on the air transport market and how these have led to a new/alternative scenario with changes in air traffic demand and aircraft production predictions. Coincidentally, along spring and fall 2020, aviation stake holders have unveiled new technology development strategies that, together with the COVID-19 impact, form a new scenario, which is assessed by comparison to the original pre-COVID-19 one.

\subsection{Impacts of COVID-19 on Air Transport Demand. Expectations for Recovery}

COVID-19 has caused an unprecedent crisis in air transport. Its effects started to be noticeable from the beginning of 2020. According to ICAO [18], overall traffic decline in 2020 will range between $53 \%$ and 59\%. Figure 3 shows the deep decline in passenger numbers and capacity offered, starting in February 2020, bottoming down in April-May 2020 (total flights accounted for $29 \%$ and $28 \%$, respectively, with respect to 2019 levels), and slightly rebounding in June 2020. 


\section{Comparison of passenger numbers and capacity} (Domestic travel is leading the recovery)

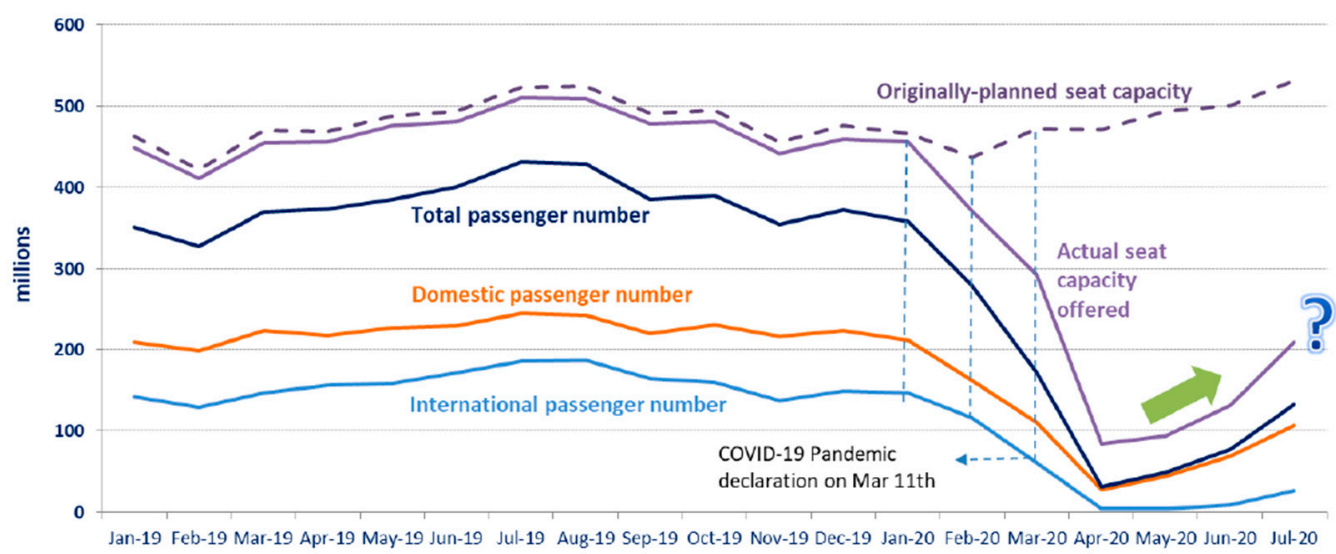

Figure 3. Drastic capacity and demand drop in 2020 due to COVID-19. Source: "Effects of Novel Coronavirus (COVID-19) on Civil Aviation: Economic Impact Analysis." [18]. Reproduced with permission from ICAO.

Traffic recovery is uncertain, depending on:

- Evolution of the disease: expansion, intensity, and duration.

- Travel restrictions and bans imposed by governments.

- Traveler perceptions of risks associated to air travelling (infection or getting stranded at destination).

- Health and safety prevention measures adopted by the air transport stakeholders.

- Market structural changes. Extension of the second wave of the pandemic during fall 2020 is likely to add to the number of airlines that went bankrupt during the first wave [69,70]. Airports Council International (ACI) warned in October 2020 of 193 European airports (mainly regional) facing insolvency in the following months [71]. As a consequence of the pandemic, governments are supporting their aviation sector under different schemes, including nationalization or state equity in some cases [23].

International traffic has been more severely affected than domestic, and its recovery is predicted to be slower. Domestic traffic's higher resilience is explained, because more than half of the world domestic traffic originates in China (first nation tackling COVID-19) and North America (the US experienced a quick recovery after April).

Regarding international traffic, since the pandemic started, planned operations have been subject to progressive withdrawals, creating a growing gap with respect to actual ones. In April 2020, global international passenger capacity experienced an estimated $94 \%$ reduction.

Private corporations need to define the right sizing to allow survival through the recession and a competitive position to afford traffic recovery afterwards. Scenario planning is the most adequate tool for this situation. ICAO [18] has simulated two potential recovery scenarios with two recovery paths each, none of which consider a full recovery by the end of 2021. Industry stakeholders' expectations [72,73] are that returning to 2019 traffic levels may happen in 2023 or 2024. The Air Transport Action Group (ATAG) considers in its WAYPOINT 2050 report [14] three alternative scenarios, where the central one would yield a traffic compound annual growth rate (CAGR) of 3\% between 2020 and 2050, yielding a $16 \%$ decrease in expected 2050 traffic with respect to their pre-COVID predictions. Low and high scenarios range from a 2.7\% CGAR (protectionism deepened scenario) and a 3.3 CAGR (return to globalization scenario). In spite of the uncertainty, the recovery of the traffic growth trail is a widely accepted scenario within the sector. Boeing [74] predicts a $4 \%$ CAGR for the 2020-2039 period, while the Japan Aircraft Development Corporation (JADC) assumes a $4 \%$ growth rate once an initial "asymptotic recovery" period towards the steady growth trail is completed [75]. Domestic and short-haul markets are forecast to 
recover more rapidly than international flights $[74,75]$ and airlines have been consequently adapting their networks to this frame [76,77].

While recovery is completed, corporations are fighting for their economic survival, so the social debate on air transport sustainability has moved to the background of the scene. However, governments and civil society are identifying this crisis as an opportunity for providing a push to aviation sustainability. Since corporations are in need of public support to survive, some governments will grant these aids conditioned to embracing sustainability commitments [78,79].

\subsection{Air Transport Supply and Future Aircraft Demand Projections in the Wake of COVID-19}

The uncertainty in the future market scenario makes it extremely difficult to produce consolidated aircraft production and fleet predictions.

Boeing and Airbus traditionally publish their long term (20 years) market forecasts in summer (late June for Boeing Commercial Market Outlook-CMO and September for Airbus Global Market Forecast-GMF). In 2020, Boeing just managed to publish a sketchy CMO [74] in October 2020, and there are no signs of Airbus 2020 GMF.

Analyzing the order books of both companies in July 2020, Airbus accounted for 7539 aircraft ordered and yet to be delivered. Since 2020 started, 369 orders have been issued and 67 orders have been cancelled, yielding a net 302 new orders. Aircraft deliveries in this period are limited to 245 [80]. Compared to the May 2019 situation depicted in part 1 , it can be observed that despite the relative low number of orders and the numerous cancellations, the orders backlog has increased from 7207 to 7539 . This is explained by the very low number of deliveries, 245 for seven months. Airbus is negotiating with customers' postponement of aircraft deliveries in an attempt to avoid cancellations [81]. Airbus is also curtailing their production rates and downsizing their staff [20].

Boeing unfilled orders in July 2020 account for 5185 aircraft (4496 if ASC 606 accounting standard criteria are applied). The 2020 year to date gross orders are limited to 59, and the year to date deliveries account for 74 aircraft. Boeing's orders backlog has experienced a significant drop with respect to 5764 aircraft orders in May 2019. This is due to the combination of COVID-19 effects and the inability to conclude B737-MAX recertification and re-entry into service [82] that led to numerous cancellations (366 in 2020). B737-MAX orders have decreased from 4550 in May 2019 to 4127 in July 2020 [83].

The aircraft production scenario has changed very significantly since fall 2019. In consequence:

- $\quad$ The existing orders delivery schedule will expand in time. The part 1 prediction of 10 to 12 years of full occupation of production capabilities to cover the orders backlog in May 2019 is now going to be extended, as the airlines will negotiate postponement of deliveries or even cancel their orders, and as the production rates are already significantly reduced.

- $\quad$ Active aircraft operating lives will be extended. Although the global operating fleet downsize has accelerated the retirement of older and less efficient aircraft [73] and so reduced the average age of the operating fleet, this younger fleet will be operated with lower intensity, therefore requiring longer amortization times. There will be no pressure for early replacements.

- The current delivery rates would hardly satisfy the 2019 predicted renewal rates, thus leaving no room for growth unless the lives of the existing fleets are extended.

The 2019 analysis in part 1 showed how delivery commitments in existing order books and a saturated production capacity were significant constraints to the introduction of revolutionary changes in the air transport energy paradigm. In the new COVID-19 affected scenario, the constraint of the delivery commitments is still applicable and may imply an even longer time span for delivery of the existing orders with aircraft of existing technology. On the other hand, production capacity is not saturated any longer. However, this does not imply that spare engineering and manufacturing resources will be available for affording lengthy and costly technology development and demonstration processes. On the 
contrary, financial struggle caused by demand plunge is forcing aeronautics manufacturers to undertake cost reduction measures and capacity downsizing that are hampering their ability to proceed with research projects and to launch new aircraft products. Additionally, the uncertainty of the future market implies a severe difficulty for aircraft manufacturers to make decisions about which new products should be launched, in what timeframe, and which technologies should be incorporated. Moreover, the uncertainty raises doubts about market capability to host and achieve a significant deployment in the fleet of a new product.

Manufacturers are seeking institutional support to financially survive the crisis in demand while keeping the capabilities to engage with the recovery in 2021. Expectations for an earlier recovery of domestic and short haul markets are already dialed in manufacturers predictions for fleet renewal and growth, enlarging the traditional difference between expected narrow-body and wide-body production rates [74,75].

Institutional support is also required to keep progressing on the technology development programmes aiming at improving aircraft sustainability and efficiency, maintaining the expectation of a significant deployment of aircraft with enhanced propulsion systems (UltraFan ${ }^{\circledR}$ and potentially Propfan at a later stage) in the midterm. In a limited traffic growth scenario, the efficiency improvements offered by these architectures become more relevant and might be enough to achieve fleet emissions' neutral growth.

\subsection{Technology Development Strategies Evolution in 2020}

Chapter 4 of part 1 discussed the technology developments with potential for aviation system energy consumption reduction. Parallel to COVID-19, some significant events and strategy changes have occurred, affecting the plans to develop said technologies.

1. Air traffic control. In their European Networks Operations Plan. 2020 Recovery Plan, EUROCONTROL [84] calculates the impossibility to derive a full year traffic forecast as well as consistent and specific air traffic improvement goals. A generic intent to improve overall performance by minimizing air space utilization constraints, allowing for optimization of trajectories, is declared and applied, allowing for distance flown savings up to 26,000 NM per day. Recommendations to use advance navigation capabilities and continuous descent operations are also issued.

2. Aircraft improvements. The pressure to achieve marginal aerodynamic, system, and weight improvements still stands. New discussions about changes in aircraft architecture have been triggered by the surging interest in hydrogen powered aviation that will be discussed later. In September 2020, Airbus has revealed three zero emissions concepts relying on hydrogen combustion, one of them being a blended wing body [26].

3. Improvements in aircraft propulsion systems. The debate about the most adequate revolutionary propulsion system has significantly changed its direction since fall 2019.

(a) Propfan. After running some engine demonstration tests started in 2017 in the frame of Clean Sky 1 (open rotor concept), subsequent aircraft integration viability analyses have been carried out within the Clean Sky 2 program, aiming at their conclusion in 2020 [85]. However, there is not currently a program decision to introduce the open rotor in a flight demonstrator.

(b) Turbofan with reduction gearbox and high bypass ratio. Development of the UltraFan ${ }^{\circledR}$ engine technology demonstrator led by Rolls Royce has continued during 2020 within Clean Sky 2. Manufacturing of the first engine parts have started, and design is intended to be frozen in 2020 [85] to run the first ground test demonstrator in 2021. Simultaneously, engine-aircraft integration definition is being progressed, and readiness for flight test in Rolls Royce B747-400 flying test bed is being worked out. Therefore, despite the global financial and economic trouble, the UltraFan ${ }^{\circledR}$ program progresses firmly. Since engine-aircraft integration within Clean Sky 2 is done partnering up with Airbus, opportunities to introduce UltraFan ${ }^{\circledR}$ engine technology in potential 
new Airbus developments are maximized. Additionally, in January 2020, Boeing announced a clean-sheet re-evaluation of the B-797 project, which will allow for UltraFan ${ }^{\circledR}$ technology maturation before program launch. These events further confirm part 1 conclusion regarding feasibility of UltraFan ${ }^{\circledR}$ engine technology application in a significant part of the fleet in the next decades.

(c) Electrical and hybrid propulsion. In June 2020, EASA issued the first Type Certificate to a fully electrical aircraft: the Pipistrel VELIS Electro [86]. This is a general aviation two-seater with a payload of $172 \mathrm{~kg}$ and an endurance of 50 min. In April 2020, Airbus and Rolls-Royce took the decision to bring the E-Fan X hybrid propulsion demonstrator, launched in 2017, to an end. Both manufacturers reckon that the demonstrator has generated key knowledge about real potential and limitations of hybrid electric propulsion as well as for setting the basis for a regulatory framework. These events reinforce the conclusions reached in part 1 regarding the limitations in the applicability of electric or hybrid propulsion to commercial airliners and their suitability for personal/general aviation applications.

4. Alternative fuels.

In December 2019, the European Union presented "The European Green Deal" [87], resetting "the Commission's commitment to tackling climate and environmental-related challenges that is this generation's defining task." It is a new growth strategy where economic growth is decoupled from resource use and where the goal is set to produce zero greenhouse gases emissions in 2050. This comprehensive strategy includes policies for clean energy, clean industry embracing circular economy, building and construction, smart mobility, food industry, preservation of ecosystems, and air pollution. The Green Deal has created the frame to identify synergies and integrated strategies among different sectors. In early July 2020, the European Union presented "A hydrogen strategy for a climate-neutral Europe" [27], where hydrogen is identified as a key element to achieve the European Green Deal goals, as it can be used as feedstock, fuel, or energy carrier/storage, and has many applications across the industry, transport, power, and building sectors. Investment in hydrogen is considered critical for recovery from the COVID-19 crisis. The report identifies hydrogen as a potential long-term option to decarbonize aviation.

Simultaneously, McKinsey and Company published the study "Hydrogen-powered aviation" [25] procured by the Clean Sky 2 and Fuel Cells and Hydrogen 2 (FCH2) Joint Undertakings under the H2020 Framework Program. The study advocates for hydrogen to be a major part of the future propulsion technology mix. Both fuel cell based or liquid hydrogen (LH2) combustion turbines solutions (or even hybrid) are considered suitable, depending on aircraft size and range. This is a fundamental change in the decarbonization strategy of European aviation stakeholders, moving the focus from electric and hybrid electric propulsion strategies to hydrogen-based technologies. However, further investigation on aircraft systems electrification is needed in order to integrate it with LH2 fuel cells.

Use of hydrogen in aviation has been explored in the past. Sürer and Arat [88] reviewed the attempts of hydrogen use in aviation along history. Since 1956, multiple demonstrators have been developed and flown. All direct combustion demonstration programs were no further progressed into production developments. Hydrogen fuel cellbased demonstration applications have been limited to unmanned or very small aircraft.

The McKinsey study [25] concludes on the feasibility of LH2 aircraft, with estimated entry into service in 2030-2035, for short range applications (165 passenger-2000 km range), achieving a $100 \%$ decarbonization and $75 \%$ climate impact reduction. This aircraft would feature a combined fuel cell system driving electrical motors for cruise operation and direct LH2 burning turbines for take-off and climb. A significant deployment of LH2 aircraft in the world fleet in 2050 timeframe requires first achieving sufficient progress in the aircraft technology enablers and developing an integrated ecosystem to ensure LH2 production and distribution. The main technology challenges are in the required energy 
density of LH2 tanks (need to double current state of art from 6 to $12 \mathrm{kWh} / \mathrm{kg}$ ), in the required power density of fuel cell systems (need to multiply current values by a factor or $2-3$ to achieve $2 \mathrm{~kW} / \mathrm{kg}$ ), and in cryogenic fuel system safety, reliability, and durability. The strategy to pursue use of LH2 in commercial airliners has been further confirmed by Airbus announcements presenting up to four different hydrogen based aircraft concepts $[26,89]$ and by the European Commission in the "Sustainable and Smart Mobility Strategy" [28] published in December 2020.

Gaining confidence in new technologies to finally bring them into service solutions requires making them progress through the technology readiness ladder, fulfilling a sequence of phased maturity levels (technology readiness levels-TRLs), following a NASA methodology [90]. Developing and maturing new technologies has been identified as a relevant schedule risk in complex systems development [91]. The lack of technology maturity or technology uncertainty corresponding to low technology readiness levels implies a higher schedule slippage risk in systems development, close to $100 \%$ of the original schedule for complex projects. When new aircraft programs are to be launched, the technologies used should have already attained high technology readiness levels. Otherwise, the uncertainty of low readiness technologies will hinder program schedule. Combining this with the discussion about new aircraft programs duration in part 1, where it was concluded that a brand new aircraft design with high technology maturity levels at program start takes between nine and 15 years to develop, it is extremely unlikely that in a 15 year timeframe there will be a certified, ready to entry into service hydrogen airliner suitable for being significantly deployed in the world fleet.

The McKinsey report [25] also analyzes the viability of green synthetic fuels compared to the LH2 alternatives, concluding that synthetic fuels can provide better performances than hydrogen solutions for large/long range aircraft. The focus on drop-in fuels alternative to kerosene is moving from biofuels to synthetic fuels. Synthetic fuel production is between two and three times more energy intensive than hydrogen, so the long-term expectation is that synthetic fuel will exceed in $32 \%$ current kerosene-based costs for available seat kilometer, for only $25 \%$ for LH2.

Within this frame, the European Union is setting up the Future European Partnership on Clean Aviation Under Horizon Europe [92], a Joint Undertaking providing continuity to Clean Sky 2 work while strongly encouraging and promoting innovation in disruptive technologies for hybrid electric regional, ultra-efficient short, and medium range and hydrogen powered aircraft. Its goal is to develop enabling technologies up to 2030 for revolutionary aircraft concepts entering into service in 2035 to 2040 . The strategic research and innovation agenda (SRIA) [93] on which it is based describes the milestones to progress through the technology readiness, ultimately requiring flight demonstration to integrate solutions at real scale and address compliance with safety and operability requirements to achieve TRL6 (demonstration under real type operational conditions at real scale). The SRIA acknowledges the very low TRL level starting point in some LH2 enabling technologies, both for on-board application and infrastructure related. This implies a severe schedule risk to achieve the intended targets in time. Financial scarcity risk will be partially mitigated by provision of additional funds from the Next Generation EU recovery plan to research and innovation activities through the Horizon Europe program [94]. However, low TRL levels of emerging technologies, together with a yet not defined and fully funded multisectorial roadmap and the current financial distress of aeronautic companies will extend technology and even aircraft development lead times, introducing uncertainty in the time scales for extended availability of efficient emissions reduction solutions.

\subsection{Aviation Emissions Trade and Compensation Systems in 2020}

During the 40th General Assembly in October 2019, ICAO issued resolution A4019 [95], defining the mechanism for adjusting the CORSIA scheme design to evolving circumstances. 
In June 2020 the ICAO Council agreed to provide a clear safeguard to the CORSIA. CORSIA baseline emission targets were initially intended to be calculated based on an average of 2019 and 2020 emissions. The dramatic drop in 2020 traffic would consequently reduce the baseline level, potentially imposing an economic burden for airlines on their way to recovery during CORSIA pilot phase in 2021 to 2023. It was therefore agreed to use the value of 2019 emissions for 2020 emissions. Further revision of CORSIA is expected during the 2022 assembly.

It is not expected that compliance with CORSIA will imply any difficulty on the way to traffic recovery, as this will remain lower than the baseline 2019 levels for the whole pilot phase.

CORSIA adjustment mechanisms allow for its fair adaption to market conditions such as those derived from the current pandemic, where the no emissions growth target is naturally achieved by the traffic decay.

\section{PART 3. Comparison of Scenarios and Final Conclusions}

\subsection{Comparison of Scenarios: Pre-COVID-19 vs. 2020 (COVID-19 Effect and New} Technology Proposals)

Although the COVID-19 crisis has dramatically impacted air traffic demand and future predictions, putting on hold the well settled assumptions of sustained traffic growth for the next decades, the commitment of the sector to become more sustainable, and, in particular to reduce the greenhouse gas emissions to mitigate climate impact, still remains. Moreover, institutional support to operators and manufacturers is in many instances conditioned to development and adoption of climate impact contention technologies. Private entities need public support to embrace this opportunity, as their own resources will necessarily be used to cope with financial challenges derived from revenue plunge.

Drop in air traffic demand has also affected aircraft production and delivery rates. A wake of cancellations and delivery postponements is forcing aircraft and systems manufacturers to downsize their production capacity. Even if pressure in production is relaxed, financial trouble will hinder manufacturers' capacity to embark on new products and technology developments in an uncertain market that might have difficulties absorbing them.

Therefore, despite the institutional support, for both pre-COVID-19 and 2020 scenarios, market conditions do not favor the transition to a revolutionary aviation energy paradigm change. In the pre-COVID-19/sustained growth in demand scenario, the market constraint was in the combination of long aircraft order books, long operating lives, saturated production capacity, and long product development times. In the 2020 scenario, with deep and long demand decay and uncertain recovery, the market constraint changes, but does not move away. Even if order books are shrinking, the delivery times are expanding, and production capacity is being adjusted to the required production rates. Moreover, financial trouble becomes an additional constraint.

From the technology development standpoint, in the 2020 scenario, high confidence remains in the development of new propulsion platforms with classical combustion and reaction principles in the mid-term, namely the UltraFan ${ }^{\circledR}$.

Regarding more revolutionary changes, European industry and institutional focus is evolving from electrical and hybrid technology propulsion in the pre-COVID-19 scenario to liquid hydrogen (LH2). This is the result of progress made in the understanding of electric and hybrid real capabilities and a consequence of the synergies identified with other non-aviation European research initiatives focused on the use of hydrogen. Even if the technology focus has changed, in both scenarios the technologies under investigation are very far away from demonstrating their viability for an airliner service introduction and for a significant deployment in the world fleet to support a relevant reduction of emissions. Moreover, on top of aircraft changes, a complete redefinition of the aviation eco-system would be required (infrastructure, logistics, operations, etc.). 
Although evolved, the constraints for an energy paradigm change in aviation are still very significant. Figure 4 offers a comparison of the applicable constraints between the pre-COVID 19 and the 2020 scenarios. Said constraints are related to:

- Market outlook

- Development times for new aircraft models

- $\quad$ Technology strategy maturation needs

- Technology limitations

- $\quad$ Safety and certification

\begin{tabular}{|c|c|c|}
\hline & PRE COVID-19 & 2020 \\
\hline \multirow{3}{*}{ MARKET OUTLOOK } & $\begin{array}{l}\text { Constant growth in air transport } \\
\text { demand \& supply. }\end{array}$ & $\begin{array}{l}\text { Demand recession and financial scarcity } \\
\text { followed by slow/uncertain recovery. } \\
\text { Supply adjusting behind. High } \\
\text { percentage of fleet parked. }\end{array}$ \\
\hline & $\begin{array}{l}\text { Production lines saturated to honour } \\
\text { long orders backlog. }\end{array}$ & $\begin{array}{c}\text { Orders backlog stretched in time: less } \\
\text { orders, less deliveries (cancellations and } \\
\text { postponements). }\end{array}$ \\
\hline & Long aircraft operating lives. & $\begin{array}{c}\text { Early aircraft retirements (not } \\
\text { replaced). }\end{array}$ \\
\hline \multirow{3}{*}{$\begin{array}{l}\text { NEW AIRCRAFT } \\
\text { DEVELOPMENT TIMES }\end{array}$} & \multicolumn{2}{|c|}{$\begin{array}{l}\text { Earliest introduction time around } 10 \text { years from now. Could include new engine } \\
\text { architectures, but no energy paradigm change. }\end{array}$} \\
\hline & \multicolumn{2}{|c|}{ Significant introduction of $\mathrm{A} / \mathrm{C}$ with energy paradigm change beyond tw } \\
\hline & $\begin{array}{l}\text { Uncertainty in lead times increased } \\
\text { financial distress and not yet defined }\end{array}$ & $\begin{array}{l}\text { ue to new market conditions, } \\
\text { technology roadmaps. }\end{array}$ \\
\hline \multirow{3}{*}{$\begin{array}{l}\text { TECHNOLOGY STRATEGY } \\
\text { MATURATION NEEDS }\end{array}$} & \multicolumn{2}{|c|}{ New engine architectures in demonstration phase. } \\
\hline & \multicolumn{2}{|c|}{ Electrical and hybrid propulsion at early technology maturation phase. } \\
\hline & & $\begin{array}{l}\text { Hydrogen and synthetic fuel at very } \\
\text { early technology maturation phase. }\end{array}$ \\
\hline \multirow{5}{*}{ TECHNOLOGY LIMITATIONS } & \multicolumn{2}{|c|}{$\begin{array}{l}\text { New engine architectures provide a limited efficiency improvement (25-30\% } \\
\text { compared to } 2000 \text { levels). }\end{array}$} \\
\hline & \multicolumn{2}{|c|}{ Electric and hybrid limited to general aviation, some chance for regional. } \\
\hline & \multicolumn{2}{|c|}{ Biofuels cost and feedstock size and resources consumption. } \\
\hline & & $\begin{array}{l}\text { Hydrogen systems weight, } \\
\text { infrastructure and safety. }\end{array}$ \\
\hline & & Synfuel cost and infrastructure \\
\hline \multirow{3}{*}{ SAFETY/CERTIFICATION } & \multicolumn{2}{|c|}{ Working on electrical/hybrid certification base. } \\
\hline & & $\begin{array}{l}\text { First electrical aircraft (general aviation) } \\
\text { certified by EASA. }\end{array}$ \\
\hline & & $\begin{array}{l}\text { No existing certification base for } \\
\text { hydrogen aircraft. }\end{array}$ \\
\hline
\end{tabular}

Figure 4. Comparison of aviation energy paradigm change constraints in the PRE-COVID-19 and 2020 Scenarios. 2020 evolved or new elements marked in bold.

The major evolutions in 2020, after COVID, are related to demand recession and financial scarcity, uncertainty in market recovery, production capacity adjustments, orders backlog stretched in time, hydrogen aircraft and synfuel technology proposals, and the first electric aircraft certification, as can be seen in bold font. 


\subsection{Final Conclusions}

This paper examines the constraints limiting the ability of the air transport sector to implement radical changes on the aviation energy paradigm aiming at enhancing its sustainability. Two scenarios have been assessed: a traditional scenario of continuous traffic growth (pre-COVID-19) and a COVID-19 impacted scenario (2020) with a deep sink in demand and uncertain recovery. In both scenarios, severe constraints apply that prevent a radical change in the aviation energy paradigm for the next decades. Aircraft development times, compliance with safety and certification requirements, and technology maturation times remain basically the same for both scenarios, irrespective of the new technology proposals that have publicly flourished during 2020 . The new technology proposals face different technical challenges that require further maturation to guarantee feasibility of the aircraft concepts that they support, as well as a simultaneous development of infrastructure and logistics. The constraint most significantly different between both scenarios is that of the market structure: from the pre-COVID-19/sustained growth demanding full dedication and long-term commitment of saturated production and engineering capabilities to a new COVID-19 affected scenario of business downturn, financial scarcity, and uncertain yet long recovery.

Irrespective of the scenario, technology improvements as well as policy changes aiming at improving aviation sustainability should be pursued. Even if the traffic decay has reduced aviation environmental impacts very significantly, the sector needs to get prepared for an eventual recovery and remain committed to abating its emissions by reduction and compensation.

Introduction of new engine architectures allowing for $20-25 \%$ fuel consumption reduction should be expedited by bringing their demonstration programs to a conclusion. A robust private-public collaboration frame needs to be developed to support their introduction into service in the shortest possible time frame.

Longer term technologies enabling more radical concept changes need to be progressed through their maturation process in order to determine the real scope of application of aircraft products relying on them. Early definition of research policies and plans as well as early involvement of certification authorities are musts in this process. Agents of aviation and tourism shall manage expectations about aviation emissions in a realistic way, stressing the socio-economic importance of air transport.

Internalization of social and environmental costs is an undeniable responsibility of the sector that, given the technology constraints, requires relying on external compensation. Programs like CORSIA need to expedite their scope spread while ensuring a thorough mechanism to qualify tradeable emission units.

New technology proposals from the industry, based on hydrogen powered aircraft, require not only progressing in a technology maturity path as complex as electrical or hybrid technology, but also the concurrence of technology developments in the energy sector as well as the development of infrastructure and logistic systems beyond the aviation sector. The concurrence of all these multi-sector developments will necessarily have to rely on a not yet proven alignment of policies from governments and institutions, including funding schemes, and will in any case require decades to provide a suitable operating frame. Therefore, even if traffic decrease due to COVID-19 implies a break in aviation emissions growth, when 2019 traffic level is recovered as predicted by sector analysts between 2023 to 2025, emissions will recover the rising trend as well, unless aviation grasps the opportunities whose maturation is realistically feasible in that timeframe so that any traffic growth beyond that point happens with no emissions increment. This shall necessarily rely on implementation and scope extension of emissions compensation and trading schemes such as ETS and CORSIA and in bringing into service aircraft technologies at high maturity level such as new engine architectures.

Personal motivations and commitment from the air transport stakeholders to pursue longer term technology developments towards sustainable energy paradigms as well as their confidence in their success will be a fundamental factor in the development of future 
scenarios, while it is an issue that has been little explored. Jiménez [96] discussed this topic in a time frame when hydrogen propulsion for commercial aircraft and synthetic aviation fuels were barely debated in the sector.

It is worth emphasizing that the aviation sector's management of the pandemic could be framed within the humanitarian supply chain (Habib and Sarkar, 2017) [97]. This chain consists of four phases: (i) mitigation, which includes actions taken to reduce the severity of a disaster; (ii) preparedness, which consists of activities that increase a community's ability to respond in the event of a disaster; (iii) response, which addresses the immediate threats following a disaster; and (iv) recovery, which consists of restoring infrastructure to return the community to a near-normal state. Surely aeronautical companies should consider an integrated, multi-criteria decision-making methodology model for managing the response phase in an environment of uncertainty.

Further research should be pursued to explore the real adherence of sector stakeholders to sustainability institutional policies and goals as well as their degree of personal motivation, commitment, and belief to pursue the new industry technology proposals.

Author Contributions: Conceptualization: A.J.-C. and L.R.-A.; methodology: A.J.-C.; investigation: A.J.-C., M.S.C.-P., and M.E.-C.; resources: A.J.-C. and L.R.-A.; data curation: A.J.-C., L.R.-A., and M.E.-C.; writing —original draft preparation: A.J.-C.; writing—review and editing: A.J.-C., M.S.C.-P., and L.R.-A.; visualization: A.J.-C., M.S.C.-P., and M.E.-C.; supervision: M.S.C.-P. and L.R.-A. All authors have read and agreed to the published version of the manuscript.

Funding: This research received no external funding.

Institutional Review Board Statement: Not applicable.

Informed Consent Statement: Not applicable.

Data Availability Statement: Data sharing not applicable.

Conflicts of Interest: The authors declare no conflict of interest.

\section{References}

1. Christensen, L. Environmental Impact of Long Distance Travel. Transp. Res. Procedia 2016, 14, 850-859. [CrossRef]

2. Gutiérrez, J.G. Reducir creciendo? La Estrategia del Sector Aéreo Para Mitigar su Papel en el Cambio Climático Visto desde la Soberanía Alimentaria. In International América Lat. La Auton. Una Región. Proceedings of the XV Encuentro de Latinoamericanistas Españoles; Trama Editorial; CEEIB: New York, NY, USA, 2013; pp. 898-910. Available online: http:/ /hal.archives-ouvertes.fr/ halshs-00875594/ (accessed on 30 November 2020).

3. Gössling, S.; Hall, C.M.; Peeters, P.; Scott, D. The Future of Tourism: Can Tourism Growth and Climate Policy be Reconciled? A Climate Change Mitigation Perspective. Tour. Recreat. Res. 2010, 35, 119-130. [CrossRef]

4. Hall, M. Changing Paradigms and the Global Change. From Sustainable to Steady-State Tourism. Tour. Recreat. Res. 2010, 35, 131-143. [CrossRef]

5. Hernández, J. Turismo de masas y transporte: El gran reto del turismo del siglo xxi. Scr. Nov. Rev. Electr. Geogr. Cienc. Soc. 2008, 12, 258. Available online: http:/ /www.ub.edu/geocrit/sn/sn-258.htm (accessed on 30 November 2020).

6. Peeters, P.; Higham, J.; Kutzner, D.; Cohen, S.; Gössling, S. Are technology myths stalling aviation climate policy? Transp. Res. Part D Transp. Environ. 2016, 44, 30-42. [CrossRef]

7. Popescu, G.H.; Mieila, M.; Nica, E.; Andrei, J.V. The emergence of the effects and determinants of the energy paradigm changes on European Union economy. Renew. Sustain. Energy Rev. 2018, 81, 768-774. [CrossRef]

8. Saygin, H.; Çetin, F. New Energy Paradigm and Renewable Energy: Turkey's Vision. Turkey's New Geopolit. Energy Summer 2010, 12, 107-128. Available online: https:/ /www.insightturkey.com/articles/new-energy-paradigm-and-renewable-energy-turkeysvision (accessed on 11 October 2020).

9. Ruth, M.F.; Kroposki, B. Energy Systems Integration: An Evolving Energy Paradigm. Electr. J. 2014, 27, 36-47. [CrossRef]

10. ICAO. ICAO Environmental Report 2016, Aviation and Climate Change. 2016. Available online: https://www.icao.int/ environmental-protection/pages/env2016.aspx (accessed on 30 January 2021).

11. IATA. Fuel Fact Sheet. IATA 2019. No. December 2019, p. 1. Available online: https://www.iata.org/pressroom/facts_figures/ fact_sheets/Documents/fact-sheet-fuel.pdf (accessed on 30 January 2021).

12. IATA. Aviation and Climate Change-Fact Sheet. 2019. Available online: https://www.iata.org/en/iata-repository/pressroom/ fact-sheets /fact-sheet--climate-change/ (accessed on 30 January 2021).

13. IEA. Aviation 2020 Tracking Report 2020. Available online: https://www.iea.org/reports/aviation\#resources (accessed on 30 January 2021). 
14. ATAG Air Transport Action Group. Waypoint 2050. Balancing Growth in Connectivity with a Comprehensive Global Air Transport Response to the Climate Emergency. 2020. Available online: https:/ / aviationbenefits.org/environmental-efficiency/ climate-action/waypoint-2050/ (accessed on 30 January 2021).

15. ICAO. ICAO and the United Nations Sustainable Development Goals. ICAO AVIATION DEVELOPMENT, 2020. Available online: https:/ / www.icao.int/about-icao/aviation-development/Pages/SDG.aspx (accessed on 29 November 2020).

16. Eurocontrol. European Aviation in 2040. Challenges of Growth. 2018. Available online: https://www.eurocontrol.int/ publication/challenges-growth-2018 (accessed on 29 November 2020).

17. Japan Aircraft Development Corporation. Positioning of JADC 's Demand Forecast Over COVID-19. 2020. Available online: http: / / www.jadc.jp / files / topics /159_ext_01_en_0.pdf (accessed on 30 July 2020).

18. International Civil Aviation Organization (ICAO). Effects of Novel Coronavirus (COVID-19) on Civil Aviation: Economic Impact Analysis Air Transport Bureau Contents. 2020. Available online: https://www.icao.int/sustainability/Documents/COVID-19 /ICAO_Coronavirus_Econ_Impact.pdf (accessed on 29 November 2020).

19. Boeing. Boeing CEO Updates Employees on Quarterly Results and Market Realities. Boeing Media Press Releases. 29 July 2020 Available online: https:/ / boeing.mediaroom.com/news-releases-statements?item=130713 (accessed on 25 November 2020).

20. Airbus. Airbus Plans to Further Adapt to COVID-19 Environment. Airbus Media. 30 June 2020. Available online: https://www. airbus.com/newsroom/press-releases/en/2020/06/airbus-plans-to-further-adapt-to-covid19-environment.html (accessed on 25 November 2020).

21. Amankwah-Amoah, J. Note: Mayday, Mayday, Mayday! Responding to environmental shocks: Insights on global airlines' responses to COVID-19. Transp. Res. Part. E Logist. Transp. Rev. 2020, 143, 102098. [CrossRef] [PubMed]

22. Amankwah-Amoah, J. Stepping up and stepping out of COVID-19: New challenges for environmental sustainability policies in the global airline industry. J. Clean. Prod. 2020, 271, 123000. [CrossRef]

23. Abate, M.; Christidis, P.; Purwanto, A.J. Government support to airlines in the aftermath of the COVID-19 pandemic. J. Air Transp. Manag. 2020, 89, 101931. [CrossRef]

24. Gössling, S. Risks, resilience, and pathways to sustainable aviation: A COVID-19 perspective. J. Air Transp. Manag. 2020, 89, 101933. [CrossRef]

25. McKinsey \& Company. Hydrogen-Powered Aviation; Clean Sky 2 JU \& FCH JU. Publications Office of the European Union, Luxembourg; McKinsey \& Company: Chicago, IL, USA, 2020. [CrossRef]

26. Airbus. Airbus Reveals New Zero-Emission Concept Aircraft. Airbus, 2020. Available online: https://www.airbus.com/ newsroom/press-releases/en/2020/09/airbus-reveals-new-zeroemission-concept-aircraft.html (accessed on 25 October 2020).

27. Martynov, A.; Sushama, L.; Laprise, R. Simulation of temperate freezing lakes by one-dimensional lake models: Perfor-mance assessment for interactive coupling with regional climate models. Boreal Environ. Res. 2010, 15, 143-164. [CrossRef]

28. European Commission. Sustainable and Smart Mobility Strategy-Putting European Transport on Track for the FutureCommunication, 2020. Available online: https:/ / ec.europa.eu/info/law/better-regulation/have-your-say/initiatives/12438Sustainable-and-Smart-Mobility-Strategy (accessed on 25 October 2020).

29. United States 95th Congress. Public Law 95-504 (Aviation Deregulation Act). 1978. Available online: https://www.govinfo.gov/ content/pkg/STATUTE-92/pdf/STATUTE-92-Pg1705.pdf\#page=1 (accessed on 20 October 2020).

30. Japan Aircraft Development Corporation. Worldwide Market Forecast 2019-2038, 2019. Available online: http:/ /www.jadc.jp/ files/topics/157_ext_01_en_0.pdf (accessed on 3 September 2020).

31. Scott, D.; Gössling, S. What could the next 40 years hold for global tourism? Tour. Recreat. Res. 2015, 40, 269-285. [CrossRef]

32. Gössling, S.; Cohen, S. Why sustainable transport policies will fail: EU climate policy in the light of transport taboos. J. Transp. Geogr. 2014, 39, 197-207. [CrossRef]

33. Ram, Y.; Nawijn, J.; Peeters, P.M. Happiness and limits to sustainable tourism mobility: A new conceptual model. J. Sustain. Tour. 2013, 21, 1017-1035. [CrossRef]

34. Higham, J.E.S.; Cohen, S.A.; Cavaliere, C.T.; Reis, A.C.; Finkler, W. Climate change, tourist air travel and radical emissions reduction. J. Clean. Prod. 2016, 111, 336-347. [CrossRef]

35. Larsen, G.R.; Guiver, J.W. Understanding tourists' perceptions of distance: A key to reducing the environmental impacts of tourism mobility. J. Sustain. Tour. 2013, 21, 968-981. [CrossRef]

36. Airbus. Global Market Forecast 2018-2037, 2018. Available online: https://www.airbus.com/aircraft/market/global-marketforecast.html (accessed on 30 July 2020).

37. Boeing Commercial Aviation. Boeing Commercial Market Outlook 2019-2038, 2019. Available online: https://invest-indiarevamp-static-files.s3.ap-south-1.amazonaws.com/s3fs-public/2019-12/cmo-sept-2019-report-final.pdf (accessed on 30 July 2020).

38. Rolls Royce. Future Products-Rolls-Royce, Rolls Royce Website, 2020. Available online: https:/ /www.rolls-royce.com/productsand-services / civil-aerospace/future-products.aspx\#/ (accessed on 25 October 2020).

39. Maoui, G. Innovation Takes Off. Clean Sky; Le Cherche Midi: Paris, France, 2016.

40. Badánik, B.; Götz, K. Aircraft manufacturers marketing warfare. In Proceedings of the MATEC Web of Conferences, České Budějovice, Czech Republic, 6-7 November 2018; Volume 236, p. 01006. 
41. Guyon, I.; Amine, R.; Tamayo, S.; Fontane, F. Analysis of the opportunities of industry 4.0 in the aeronautical sector. In Proceedings of the IMCIC 2019 10th International the Multi-Conference Complexity, Informatics Cybern, Orlando, FL, USA, 12-15 March 2019; Volume 2, pp. 62-67.

42. UNEP-UNWTO-WMO. Climate Change and Tourism: Responding to Global Challenges Advanced Summary October 2007, 2007. Available online: https://www.uncclearn.org/wp-content/uploads/library/summ.pdf (accessed on 30 August 2020).

43. OPEC. World Oil Outlook. 2016. Available online: https://www.opec.org/opec_web/static_files_project/media/downloads/ publications/WOO\%202016.pdf (accessed on 30 August 2020).

44. SESAR Joint Undertaking, SESAR Joint Undertaking I Objectives. Available online: https://www.sesarju.eu/approach/objectives (accessed on 25 November 2020).

45. Sinnett, M. Saving Fuel and Enhancing Operational Efficiencies. 2007. Available online: https://www.boeing.com/commercial/ aeromagazine/articles/qtr_4_07/article_02_1.html (accessed on 30 July 2020).

46. Zhang, J.; Zhou, Z.; Zhang, F.; Tan, Y.; Yi, R. Molding process and properties of continuous carbon fiber three-dimensional printing. Adv. Mech. Eng. 2019, 11. [CrossRef]

47. National Transportation Safety Board. Aircraft Incident Report Auxiliary Power Unit Battery Fire Japan Airlines Boeing 787-8; JA829J; National Transportation Safety Board: Boston, MA, USA, 2013.

48. National Transportation Safety Board. NTSB Issues Recommendations on Certification of Lithium-Ion Batteries and Emerging Technologies I Airways Magazine. 2014. Available online: https:/ / airwaysmag.com/airlines/ntsb-issues-recommendations-oncertification-of-lithium-ion-batteries-and-emerging-technologies/ (accessed on 25 October 2020).

49. Liebeck, R.H. Design of the Blended Wing Body Subsonic Transport. J. Aircr. 2004, 41, 10-25. [CrossRef]

50. International Energy Agency. Transport Energy and CO2: Moving towards Sustainability. 2009. Available online: https: / / www.iea.org/news/transport-energy-and-co2-moving-toward-sustainability (accessed on 15 August 2020).

51. Wiriadidjaja, S.; Zhahir, A.; Mohamad, Z.H.; Razali, S.; Puaat, A.A.; Ahmad, M.T. Wing-in-ground-effect craft: A case study in aerodynamics. Int. J. Eng. Technol. 2018, 7, 5-9. [CrossRef]

52. Cole, W. The Pelican: A Big Bird for the Long Haul. Boeing Frontiers Online. 2002. Available online: https://www.boeing.com/ news / frontiers/archive/2002/september/i_pw.html (accessed on 5 September 2020).

53. Yin, C.M.; Wiriadidjaja, S.; Majid, D.L.A.H.A.; Romli, F.I.; Shakrine, A.; Rafie, M.; Zhahir, A. Review on the cost and performance of a WIGE craft: A commercialization prospective. ARPN J. Eng. Appl. Sci. 2015, 10, 10027-10033.

54. Pagowski, Z.T.; Szafran, K. Ground effect' Inter-Modal Fast Sea Transport. Trans. Nav. Int. J. Mar. Navig. Saf. Sea Transp. 2014, 8, 317-320. [CrossRef]

55. Mewhinney, M. NASA Testing New, Powerful ‘Ducted Fan' Engine for Civil Jets. NASA, Ames Research Center, 1993. Available online: https: / / www.nasa.gov/home/hqnews/1993/93-103.txt (accessed on 15 September 2020).

56. Hepperle, M. Electric Flight-Potential and Limitations. In Proceedings of the Conference: AVT-209 Workshop on Energy Efficient Technologies and Concepts Operation, Lisbon, Portugal, 22-24 October 2012; pp. 1-30.

57. Boeing. Boeing 737 Airplane Characteristics for Airport Planning. Document Number D6-58325-6 Rev. A Boeing Commercial Aircraft 2020 p. 307. Available online: http:/ /www.dept.aoe.vt.edu/ mason/Mason_f/B737.pdf (accessed on 25 October 2020).

58. Airbus. Airbus, Rolls-Royce, and Siemens team up for electric future Partnership launches E-Fan X hybrid-electric flight demonstrator. Airbus Media. 28 November 2017. Available online: https://www.airbus.com/newsroom/press-releases/en/2017 /11/airbus--rolls-royce--and-siemens-team-up-for-electric-future-par.html (accessed on 25 October 2020).

59. Benito, A.; Benito, E. Descubrir el Transporte Aéreo y el Medio Ambiente; AENA: Madrid, Spain, 2012; ISBN 9788415616559.

60. Gascón Gutiérrez, J. Aproximaciones sociológicas y antropológicas al fenómeno del turismo. In Turismo, Cultura y Sociedad; Universitat Oberta de Catalunya UOC: Barcelona, Spain, 2014; pp. 31-34.

61. García, A. Uso de biocombustibles en la aviación comercial. ACTA Autores Cient. Técn. Acad. 2010, 58, 105-112.

62. European Commission. 2 Million Tons Per Year: A Performing Biofuels Supply Chain for EU Aviation August 2013 Update, 2013. Available online: https:/ / ec.europa.eu/energy/sites/ener/files/20130911_a_performing_biofuels_supply_chain.pdf (accessed on 25 October 2020).

63. International Civil Aviation Organization (ICAO). Asamblea-37 Periodo De Sesiones. 2010. Available online: https:/ /www. icao.int/Meetings/AMC/Assembly37/Documents/ProvisionalEdition/a37_res_prov_es.pdf (accessed on 29 November 2020).

64. International Civil Aviation Organization (ICAO). Asamblea-38 Período De Sesiones. 2013, p. 128. Available online: https: / / www.icao.int/Meetings/a38/Documents/10024_es.pdf (accessed on 29 November 2020).

65. International Civil Aviation Organization (ICAO). Asamblea-39 Periodo de Sesiones. 2016. Available online: https://www. icao.int/Meetings/a39/Documents/10082_es.pdf (accessed on 29 November 2020).

66. ICAO. What Would Be the Impact of Joining CORSIA? ICAO ENVIRONMENT, 2020. Available online: https://www.icao.int/ environmental-protection/pages/a39_corsia_faq3.aspx (accessed on 29 November 2020).

67. van Velzen, A.; de Bruyn, S.; Bachaus, A. Costs of EU ETS and CORSIA for European Aviation. 2019. Available online: https: / / www.ce.nl/publicaties/download/2961 (accessed on 20 September 2020).

68. Gössling, S.; Humpe, A.; Bausch, T. Does 'flight shame' affect social norms? Changing perspectives on the desirability of air travel in Germany. J. Clean. Prod. 2020, 266. [CrossRef] 
69. Bloom, L.B.; You won't Believe How Many Airlines Haven't Survived Coronavirus. How Does It Affect You? ForbesWomen. Available online: https://www.forbes.com/sites/laurabegleybloom/2020/06/27/airlines-coronavirus-travel-bankruptcy/?sh= e56e3495f696 (accessed on 28 November 2020).

70. IATA. Looming Cash Crisis Threatens Airlines. Press Release 79. Available online: https://www.iata.org/en/pressroom/pr/20 20-10-06-01/ (accessed on 28 November 2020).

71. ACI Airports Council International. Almost 200 European Airports Facing Insolvency in Coming Months. ACI Europe. Available online: https: / www.aci-europe.org/media-room/279-almost-200-european-airports-facing-insolvency-in-coming-months. html (accessed on 5 December 2020).

72. Flottau, J.; Massy-Beresford, H.; Schofield, A.; Goldstein, B. Airline Industry Starts High-Risk Relaunch. Aviation Week. 2020. Available online: https:/ /www.britishaviationgroup.co.uk/news/airline-industry-starts-high-risk-relaunch/ (accessed on 5 December 2020).

73. Petchenik, I. How Airlines have Managed Their Fleet Mix during the COVID-19 Pandemic I Flightradar24 Blog. FlightRadar24. 26 June 2020. Available online: https: / / www.flightradar24.com/blog/how-airlines-have-managed-their-fleet-mix-during-thecovid-19-pandemic/ (accessed on 5 December 2020).

74. Boeing Commercial Aviation. Boeing Commercial Market Outlook 2020-2039, 2020. Available online: https://www.boeing.com/ resources/boeingdotcom/market/assets/downloads/2020_CMO_PDF_Download.pdf (accessed on 5 December 2020).

75. Japan Aircraft Development Corporation. Worldwide Market Forecast, 2020. Available online: http://www.jadc.or.jp/wmf13.pdf (accessed on 5 December 2020).

76. Blancmont, T. Vueling annonce le lancement de trois lignes domestiques en France. Air J. 2020. Available online: https: / / www.air-journal.fr/ 2020-09-22-vueling-annonce-le-lancement-de-trois-lignes-domestiques-en-france-5222842.html (accessed on 1 December 2020).

77. Calvo, L. Volotea Solo cae un 23 por Ciento en el Tercer Trimestre de 2020. Flynews. Available online: https:/ / fly-news.es/ aviacion-comercial/volotea-solo-cae-23-ciento-tercer-trimestre-2020/ (accessed on 1 December 2020).

78. de Best, R. Bail or bust for Europe's airlines. June 26, 2020. Stat. Infographics. 2020. Available online: https://www.statista.com/ chart/22121/airline-bailouts-in-europe/ (accessed on 25 November 2020).

79. Lyle, C. Beyond ICAO's CORSIA: Towards a More Climatically Effective Strategy for Mitigation of Civil Aviation Emissions. Clim. Law 2018, 8, 1-2. [CrossRef]

80. Airbus. Orders July 2020. Airbus Commercial Aircraft. Downloaded 18 August 2020. Available online: https://www.airbus. com/aircraft/market/orders-deliveries.html (accessed on 25 November 2020).

81. Wert, J. Airbus delivered 14 airplanes in April as airlines revise orders. International Flight Network. International Flight Network. 7 May 2020. Available online: https:/ / www.ifn.news/posts/airbus-delivered-14-airplanes-in-april-as-airlines-revise-orders / (accessed on 25 October 2020).

82. Oestergaard, J.K. Airbus and Boeing Report June 2020 Commercial Aircraft Orders and Deliveries-Defense Security Monitor; Defense \& Security Monitor, Forecast International: Newtown, CT, USA, 2020. Available online: https://dsm.forecastinternational. com/wordpress/2020/07/16/airbus-and-boeing-report-june-2020-commercial-aircraft-orders-and-deliveries / (accessed on 25 October 2020).

83. Boeing. Boeing Orders and Deliveries July 2020. Downloaded 19th Aug 2020. Boeing Commercial Aviation, 2020. Available online: https:/ / www.boeing.com/commercial/\#/orders-deliveries (accessed on 25 October 2020).

84. EUROCONTROL. European Network Operations Plan 2020 Recovery Plan, 2020. Available online: https: / /www.eurocontrol. int/sites/default/ files/publication/files/european-network-operations-plan-2016-2020.pdf (accessed on 25 October 2020).

85. Clean Sky 2 Joint Undertaking. Clean Sky 2 Joint Undertaking Bi-Annual Work Plan and Budget 2020-2021, 2019. Available online: https:/ / www.cleansky.eu/sites/default/files/inline-files/CS-GB-2019-11-21\%20WP\%20Budget\%202020-21.pdf (accessed on 25 September 2020). [CrossRef]

86. EASA. Type-Certificate Data Sheet No. EASA.A.573 for Type Virus SW 121, 2020. Available online: https:/ / www.easa.europa.eu/ sites/default/files/dfu/tcds_easa.a.573_is.5_0.pdf (accessed on 25 October 2020).

87. European Commission. The European Green Deal, 2019. Available online: https://ec.europa.eu/info/publications/ communication-european-green-deal_en (accessed on 22 August 2020).

88. Sürer, H.T.; Arat, M.G. State of Art of Hydrogen Usage as a Fuel on Aviation. January, 2018. Available online: https://www. researchgate.net/publication/322056332_State_of_art_of_hydrogen_usage_as_a_fuel_on_aviation (accessed on 1 June 2020). [CrossRef]

89. Airbus. These Pods Could Provide a Blueprint for Future Hydrogen Aircraft. Airbus Media. 15 December 2020. Available online: https://www.airbus.com/newsroom/stories/hydrogen-pod-configuration.html (accessed on 28 December 2020).

90. Mankins, J.C. Technology Readiness Levels. In NASA White Paper; Office of Space Access and Technology: Washington, DC, USA, 1995.

91. Dubos, G.F.; Saleh, J.H.; Braun, R. Technology Readiness Level, Schedule Risk and Slippage in Spacecraft Design: Data Analysis and Modeling. In Proceedings of the AIAA SPACE 2007 Conference \& Exposition 2007, Long Beach, CA, USA, 18-20 September 2007. [CrossRef] 
92. European Commission. Call for Expressions of Ideas/Potential Members for the Future European Partnership on Clean Aviation under Horizon Europe 2020. Available online: https:/ / ec.europa.eu/info/news/new-call-ideas-clean-aviation-partnerships-20 20-aug-26_en (accessed on 28 December 2020).

93. SRIA Preparatory Group. Strategic Research and Innovation Agenda. The Proposed European Partnership for Clean Aviation. 2020. Available online: https://www.clean-aviation.eu/files/Clean_Aviation_SRIA_R1_for_public_consultation.pdf (accessed on 28 December 2020).

94. EUROPEAN COMMISSION. EU'S Next Long-Term Budget \& NextGenerationEU: Key Facts and Figures, 2020. Available online: https:/ / ec.europa.eu/info/sites/info/files/about_the_european_commission/eu_budget/mff_factsheet_agreement_ en_web_20.11.pdf (accessed on 28 December 2020).

95. ICAO. ICAO Resolution A40-19. Consolidated Statement of Continuing ICAO Policies and Practices Related to Environmental Protection-Carbon Offsetting and Reduction Scheme for International Aviation (CORSIA), 2019. Available online: https: //www.icao.int/environmental-protection/Documents / Assembly/Resolution_A40-19_CORSIA.pdf (accessed on 24 August 2020).

96. Jiménez, A. Análisis de la sostenibilidad energética del transporte aéreo y su impacto en el turismo. Investig. Turísticas 2020, 20, 31. [CrossRef]

97. Habib, M.S.; Sarkar, B. An integrated location-allocation model for temporary disaster debris management under an uncertain environment. Sustainability 2017, 9, 716. [CrossRef] 